\title{
Investigation of Anti-Alga Properties and Anti-Bacteria Effects of Composite Nanofiltration Membranes Based on Chitosan Derivatives
}

\author{
J. Miao, H. C. Lin, and L. C. Zhang
}

\begin{abstract}
The anti-alga properties and anti-bacteria effects of composite nanofiltration (NF) membranes prepared from sulfated chitosan (SCS) and N, O-carboxymethyl chitosan (NOCC) were investigated in this study. The base membranes, polyacrylonitrile (PAN) and polysulfone (PS) ultrafiltration (UF) membranes, were used to be as the controls. Compared with the controls, the adsorptions of the alga on the composite NF membranes were less severe. It suggested that the SCS and NOCC composite NF membranes have anti-alga and antifouling abilities. The chosen bacteria were escherichia coli, bacillus subtilis, staureus, penicillium chrysogenum, and streptomyces jinyangensis. By comparing the colony diameters of different bacteria on various membranes and the growth of bacteria after different time periods, the qualitative conclusions of the anti-bacterial effects of the membranes were drawn. It suggested that all the investigated membranes have some anti-bacterial effects on the five kinds of bacteria and the anti-bacterial effects are related to the active layer material of the composite NF membrane and the cross-linking agent.
\end{abstract}

Index Terms-Composite NF membrane, sulfated chitosan (SCS), N, O-carboxymethyl chitosan (NOCC), anti-alga and anti-bacterial abilities.

\section{INTRODUCTION}

Among the polysaccharides, chitosan has been investigated extensively in the industries due to its excellent film-forming, antimicrobial, physical and mechanical properties [1]-[3]. Chitosan could inhibit the growth of numerous species of bacteria, pathogens, and fungi [4]-[9]. Chitosan derivatives also have the inhibition effects on bacteria. For example, carboxymethyl chitosan have different inhibition effects on Staphylococcus aureus, pseudomonas aeruginosa, salmonella typhi, escherichia coli (E. coli), isospora belli, streptococcus mutans, oral lactobacilli [10]-[13]. J. W. Song et al. [14] synthesized anti-microbial soldium alginate (SA) with chito-oligosaccharid (COS): SA-COS showed excellent anti-microbial activity with the growth of microorganisms completely suppressed by a small

Manuscript received May 10, 2014; revised July 16, 2014. This work was supported in part by the National Centre Excellence in Desalination, Australia (NCEDA) (Project No. 23634) and the ECU Innovator Awards (Project No. 23641), and National Science Foundation of China (Grant No. 61201071).

J. Miao and L. C. Zhang are with the School of Engineering, Edith Cowan University, 270 Joondalup Drive, Joondalup, Perth, WA 6027, Australia (e-mail:1.zhang@ecu.edu.au, lchangimr@gmail.com).

H. C. Lin is with the Key Laboratory of Polar Materials and Devices, Ministry of Education, East China Normal University, Shanghai 200241, China (e-mail: hclin@ee.ecnu.edu.cn). amount of COS (1.8 wt \%). The crosslinked chitosan also has excellent bactericidal action [15]-[17].

In this work, the anti-alga and anti-bacteria effects of the crosslinked thin-film composite (TFC) nanofiltration (NF) membranes using sulfated chitosan (SCS) and $\mathrm{N}$, O-carboxymethyl chitosan (NOCC) as the active layer materials were investigated preliminarily. The base membranes as the support for the active layer, PAN and PS UF membranes were employed as the control membranes for the anti-alga and anti-bacteria tests. The anti-alga effects of the SCS and NOCC composite membranes were analyzed qualitatively after comparing the adsorptions of the alga on the base membranes and the composite NF membranes.

The chosen bacteria were E. coli, bacillus subtilis, staureus, penicillium chrysogenum, and streptomyces jinyangensis. The qualitative conclusions of the anti-bacteria effects of the membranes were drawn after comparing the colony diameter of different bacteria on various composite NF membranes and the bacteria growth after different time periods.

\section{EXPERIMENTAL SECTION}

\section{A. Materials}

SCS and NOCC composite NF membranes were fabricated according to the preparation technologies in the references, surface crosslinked with hexamethylene diisocyanate (HDI), glutaraldhyde (GA), and epichlorohydrin (ECH), respectively. Table I shows the characteristics of these two series of composite NF membranes.

PAN UF membrane was self-cast and PS UF membranes were provided by Hangzhou Water Treatment Technology Development Center, China. The water samples containing freshwater alga were taken from a pond. Beef extract, peptone, sodium chloride, agar, and other reagents were of analytical grade. E. coli, bacillus subtilis, staureus, penicillium chrysogenum, and streptomyces jinyangensis, were provided by a Microbiology Laboratory. All the bacteria were activated and purified before using.

\section{B. Experimental Methods}

\section{1) Anti-alga tests}

The composite NF membranes and their base membranes (PAN, PS UF membranes) were immersed in freshwater containing alga, under the irradiation of sunlight. 26 days later, the adsorptions of freshwater alga on the membrane surfaces were observed with OLYMPUS BX51 Microscope (OLYMPUS Optical Co., Ltd., Japan): magnification: 40×10 
for more severe adsorption; $10 \times 10$ for no or light adsorption.

TABLE I: CHARACTERISTICS OF SCS \& NOCC COMPOSITE NF MEMBRANES

\begin{tabular}{|c|c|c|c|c|c|c|c|c|c|c|c|}
\hline \multirow{2}{*}{\multicolumn{2}{|c|}{$\begin{array}{c}\text { Gradient } \beta \text { of Zeta Potential } \\
(E) \text { vs. operating pressure } \\
(\Delta P) \\
\end{array}$}} & \multicolumn{2}{|c|}{ GA-SCS/PAN [18] } & \multicolumn{2}{|c|}{ ECH-SCS/PS [19] } & \multicolumn{2}{|c|}{ HDI-SCS/PAN [20] } & \multicolumn{2}{|c|}{ GA-NOCC/PS [21] } & \multicolumn{2}{|c|}{ ECH-NOCC/PS [22] } \\
\hline & & \multicolumn{2}{|c|}{-10.3} & \multicolumn{2}{|c|}{-8.78} & \multicolumn{2}{|c|}{-10.5} & \multicolumn{2}{|c|}{-8.00} & \multicolumn{2}{|c|}{-6.00} \\
\hline \multicolumn{2}{|c|}{$\begin{array}{l}\text { Molecular Weight cut-off } \\
(\mathrm{MWCO}) / \mathrm{Da}\end{array}$} & \multicolumn{2}{|c|}{780} & \multicolumn{2}{|c|}{925} & \multicolumn{2}{|c|}{720} & \multicolumn{2}{|c|}{625} & \multicolumn{2}{|c|}{760} \\
\hline \multicolumn{2}{|c|}{ Electrical characteristic } & \multicolumn{2}{|c|}{ Amphoteric } & \multicolumn{2}{|c|}{ Amphoteric } & \multicolumn{2}{|c|}{ Amphoteric } & \multicolumn{2}{|c|}{ Amphoteric } & \multicolumn{2}{|c|}{ Amphoteric } \\
\hline \multicolumn{2}{|c|}{$\begin{array}{c}\text { Charged groups in the active } \\
\text { layer }\end{array}$} & \multicolumn{2}{|c|}{$-\mathrm{NH}_{3}{ }^{+},-\mathrm{OSO}_{3}^{-}$} & \multicolumn{2}{|c|}{$-\mathrm{NH}_{3}^{+},-\mathrm{OSO}_{3}^{-}$} & \multicolumn{2}{|c|}{$-\mathrm{NH}_{3}^{+},-\mathrm{OSO}_{3}^{-}$} & \multicolumn{2}{|c|}{$-\mathrm{NH}_{3}^{+},-\mathrm{CH}_{2} \mathrm{COO}^{-}$} & \multicolumn{2}{|c|}{$-\mathrm{NH}_{3}^{+},-\mathrm{CH}_{2} \mathrm{COO}^{-}$} \\
\hline $\begin{array}{l}\text { Operating } \\
\text { conditions }\end{array}$ & Solute & $\begin{array}{c}\mathrm{F} / \\
\mathrm{kg} \cdot \mathrm{m}^{-2} \cdot \mathrm{h}^{-1}\end{array}$ & $\begin{array}{l}\mathrm{R} / \\
\%\end{array}$ & $\begin{array}{c}\mathrm{F} / \\
\mathrm{kg} \cdot \mathrm{m}^{-2} \cdot \mathrm{h}^{-1}\end{array}$ & $\begin{array}{l}\mathrm{R} / \\
\%\end{array}$ & $\begin{array}{c}\mathrm{F} / \\
\mathrm{kg} \cdot \mathrm{m}^{-2} \cdot \mathrm{h}^{-1}\end{array}$ & $\begin{array}{l}\mathrm{R} / \\
\%\end{array}$ & $\begin{array}{c}\mathrm{F} / \\
\mathrm{kg} \cdot \mathrm{m}^{-2} \cdot \mathrm{h}^{-1}\end{array}$ & $\begin{array}{l}\mathrm{R} / \\
\%\end{array}$ & $\begin{array}{c}\mathrm{F} / \\
\mathrm{kg} \cdot \mathrm{m}^{-2} \cdot \mathrm{h}^{-1}\end{array}$ & $\begin{array}{l}\mathrm{R} / \\
\%\end{array}$ \\
\hline \multirow{2}{*}{$\begin{array}{l}1000 \mathrm{mg} \cdot \mathrm{L}^{-1} \\
0.40 \mathrm{MPa}\end{array}$} & $\mathrm{Na}_{2} \mathrm{SO}_{4}$ & 7.1 & 92.1 & 22.9 & 90.8 & 7.1 & 89.9 & 3.0 & 92.7 & 7.9 & 90.4 \\
\hline & $\mathrm{NaCl}$ & 10.4 & 50.3 & 58.4 & 32.5 & 9.0 & 37.1 & 5.1 & 30.2 & 10.8 & 27.4 \\
\hline \multicolumn{2}{|c|}{$\begin{array}{l}\text { Rejection order to inorganic } \\
\text { electrolytes }\end{array}$} & \multicolumn{4}{|c|}{$\mathrm{Na}_{2} \mathrm{SO}_{4}>\mathrm{NaCl}>\mathrm{MgSO}_{4}>\mathrm{MgCl}_{2}$} & \multicolumn{2}{|c|}{$\begin{array}{c}\mathrm{Na}_{2} \mathrm{SO}_{4}>\mathrm{MgSO}_{4}> \\
\mathrm{NaCl}>\mathrm{MgCl}_{2}\end{array}$} & \multicolumn{4}{|c|}{$\mathrm{Na}_{2} \mathrm{SO}_{4}>\mathrm{NaCl}>\mathrm{MgSO}_{4}>\mathrm{MgCl}_{2}$} \\
\hline
\end{tabular}

TABLE II: THE BACTERIA CONCENTRATIONS

\begin{tabular}{cccccc}
\hline \hline Bactria & Bacillus subtilis & E.coli & Staureus & Penicillium chrysogenum & Streptomyces jinyangensis (5406) \\
\hline $\begin{array}{c}\text { Concentration } \\
\left(\times 10^{8} \text { cell } / \mathrm{mL}\right)\end{array}$ & 2.2 & 3.0 & 1.5 & 1.8 & 1.8 \\
\hline \hline
\end{tabular}

\section{2) Antibacterial test}

The strains were cultured under different conditions: bacillus subtilis, E. coli, and staureus cultured on beef extract peptone medium at $37^{\circ} \mathrm{C}$ for $24 \mathrm{~h}$; Penicillium chrysogenum cultured on Czapek medium slant at $28{ }^{\circ} \mathrm{C}$ for $72 \mathrm{~h}$ or more; Streptomyces jinyangensis (5406) cultured on Gauserime synthetic medium slant for 4 to 5 days. The living bacteria were counted with direct microscopic method. Table II shows the bacteria concentrations.

\section{3) Determination of anti-bacterial properties of the composite NF membranes}

All membranes were rinsed with distilled water, placed in an empty Petri dish for moist heat sterilization. The sterilized membranes were placed on the incubated plates for the parallel experiments. $20 \mathrm{uL}$ bacteria inoculums were transferred to the centers of the membrane surfaces with microinjection gun, and then the inoculated membranes were incubated for a period of time under different conditions according to the bacteria. PAN and PS UF membrane were employed as the controls. All specimens were prepared with the diameter of $15 \mathrm{~mm}$ for antibacterial tests. After incubation, the diameters of the colonies on the membrane surfaces were measured. The qualitative conclusions of the antibacterial effects of the membranes could be drawn after comparing the colony diameters of different bacteria on various membranes and the bacteria growth after different time periods.

\section{RESULTS AND DisCUSSIONS}

\section{A. Anti-Alga Properties of Composite NF Membranes}

The adsorptions of freshwater alga on the surfaces of the base membranes and the composite NF membranes were shown in Fig. 1, where the alga were mainly blue alga and green algae, a small amount of diatoms.

As could be seen clearly from Fig. 1, the alga adsorptions on SCS and NOCC composite NF membrane surfaces were not so sever as those on PS and PAN UF membranes. It might be due to charge repulsion between the alga and the surfaces of SCS and NOCC composite NF membranes. The alga surfaces are usually negatively charged, while there are negatively-charged functional groups in the active layers of both $\mathrm{SCS}$ and NOCC composite NF membranes, $-\mathrm{OSO}_{3}{ }^{-}$and $-\mathrm{CH}_{2} \mathrm{COO}^{-}$. Hence, SCS and NOCC composite NF membrane surfaces could have some anti-alga and antifouling abilities.

\section{B. Anti-Bacteria Properties of SCS and NOCC Composite NF Membranes}

Table III shows the experimental results of the growth diameters of bacteria on the membranes after different time periods, including the controls (PAN and PS UF membranes), and SCS and NOCC composite NF membranes.

By comparing the growth of different strains on the membranes, and the colony growth in $24 \mathrm{~h}$, the inhibition abilities of the membranes on different bacteria could be qualitatively analyzed. It could be known from Table II, SCS and NOCC composite NF membrane had certain inhibition effects on the growth of all five kinds of bacteria; HDI-SCS/PAN and ECH-SCS/PS had better antibacterial abilities on these bacteria. The following conclusions were drawn:

\section{1) SCS and NOCC composite NF membranes showed different inhibition abilities on different types of Bacteria}

The colonies of Bacillus subtilis on HDI-SCS/PAN and $\mathrm{ECH}-\mathrm{SCS} / \mathrm{PS}$ were smaller than those on the controls.

As for E. Coli, three kinds of composite NF membranes, ECH-SCS/PS, GA-SCS/PAN, and HDI-SCS/PAN, showed better inhibition effects. Staureus did not grow on the surface of ECH-NOCC/PS composite NF membrane, suggesting that ECH-NOCC/PS have excellent inhibition ability on it. The others showed almost the same inhibition effects on Staureus.

Considering both the growth of Penicillium chrysogenum in $48 \mathrm{~h}$ and $72 \mathrm{~h}$, the inhibition ability decreased in the order 
of HDI-SCS/PAN, ECH-NOCC/PS, and GA-SCS/PAN. However, GA-NOCC/PS, ECH-SCS/PS, and HDI-SCS/PAN, showed better inhibition effects in $24 \mathrm{~h}$.

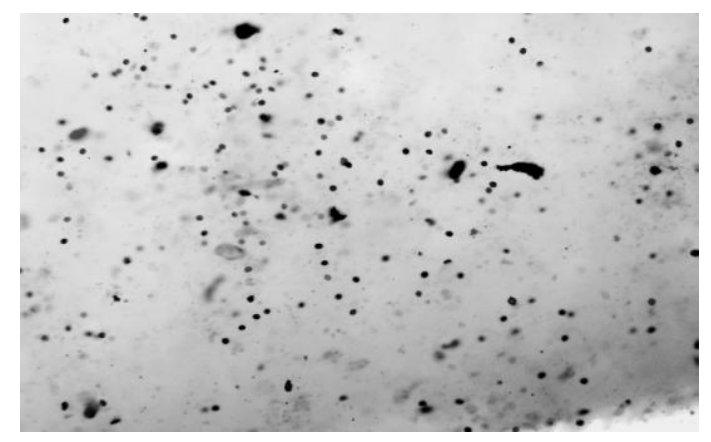

(a) PS UF membrane

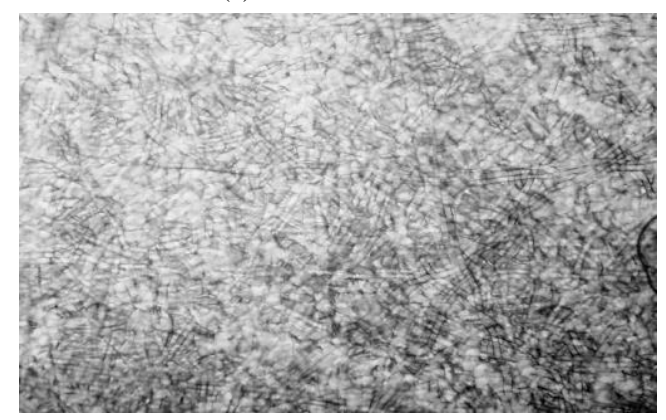

(c) ECH-NOCC/PS

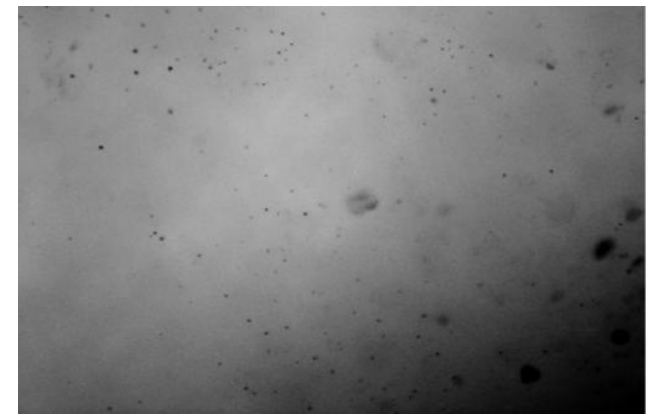

(e) GA-NOCC/PS
Compared with the other composite NF membranes, HDI-SCS/PAN and ECH-SCS/PS showed better inhibition effects on Streptomyces jinyangensis (5406).

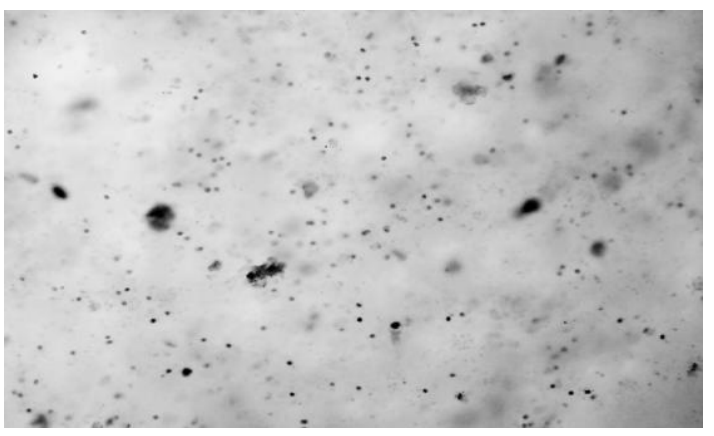

(b) PAN UF membrane

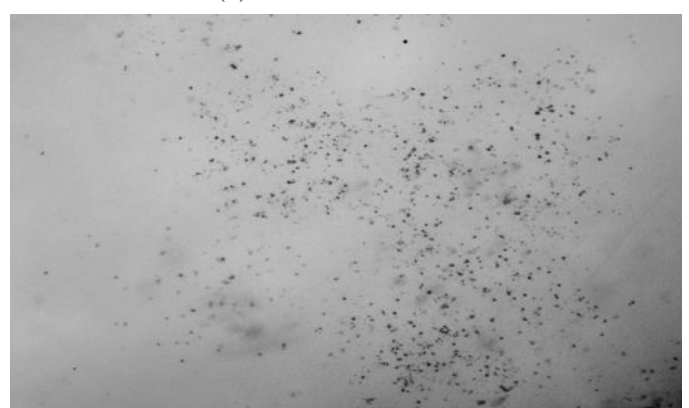

(d) ECH-SCS/PS

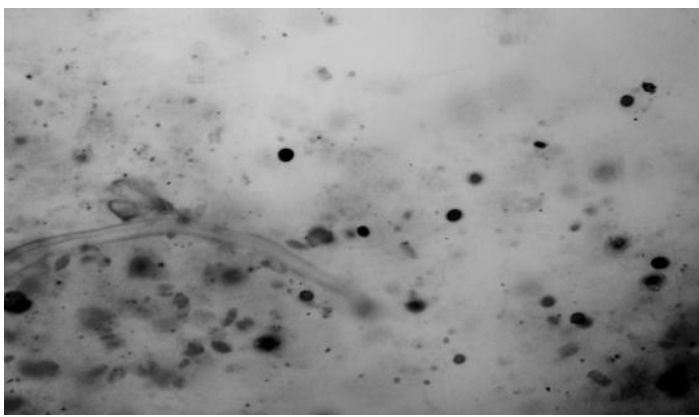

(f) HDI-SCS/PAN

Fig. 1. The adsorption of alga on the base membranes and the composite NF membranes.

TABLE III: THE GROWTH DIAMETERS OF BACTERIA ON THE MEMBRANES AFTER DIFFERENT TIME PERIODS

\begin{tabular}{|c|c|c|c|c|c|c|c|}
\hline & PAN & PS & ECH-NOCC/PS & ECH-SCS/PS & GA-NOCC/PS & HDI-SCS/PAN & GA-SCS/PAN \\
\hline Bacillus subtilis & 10.5 & 7.7 & 8.5 & 5.5 & 7.5 & 5.3 & 7.7 \\
\hline E. Coli & 9.3 & 8.0 & 8.0 & 5.1 & 6.0 & 5.8 & 5.3 \\
\hline \multirow[t]{2}{*}{ Staureus } & 9.0 & 8.3 & - & 5.6 & 6.8 & 6.0 & 6.0 \\
\hline & PAN & PS & ECH-NOCC/PS & ECH-SCS/PS & GA-NOCC/PS & HDI-SCS/PAN & GA-SCS/PAN \\
\hline Penicillium chrysogenum in $48 \mathrm{~h}$ & 8.0 & 9.5 & 6.0 & 8.0 & 9.0 & 4.7 & 7.3 \\
\hline Penicillium chrysogenum $72 \mathrm{~h}$ & 8.5 & 10.5 & 7.0 & 8.3 & 9.0 & 5.5 & 11.0 \\
\hline Streptomyces jinyangensis (5406) $72 \mathrm{~h}$ & 7.1 & 9.1 & 9.5 & 5.9 & 7.9 & 4.5 & 7.1 \\
\hline Streptomyces jinyangensis (5406) $96 \mathrm{~h}$ & 9.0 & 9.5 & 9.5 & 6.5 & 8.5 & 6.0 & 9.0 \\
\hline
\end{tabular}

\section{2) Different composite NF membranes shows different} inhibition effects on bacteria

ECH-NOCC/PS composite NF membrane could inhibit the growth of staureus completely, streptomyces jinyangensis (5406) in $24 \mathrm{~h}$, also inhibit penicillium chrysogenum well, but showed bad inhibition effects on bacillus subtilis and E. Coli.

ECH-SCS/PS composite NF membrane could inhibit bacillus subtilis, E. Coli., staureus, and streptomyces jinyangensis (5406) well, but showed bad effect on penicillium chrysogenum in $48 \mathrm{~h}$.
GA-NOCC/PS composite NF membrane inhibited E. Coli., staureus, and streptomyces jinyangensis (5406) well. The colony diameter of penicillium chrysogenum did not change after $24 \mathrm{~h}$, suggesting it also could inhibit penicillium chrysogenum well. Its inhibition effect on bacillus subtilis was not so good as on the other four bacteria.

HDI-SCS/PAN inhibited all five kinds of bacteria well.

GA-SCS/PA showed not good inhibition effects on the other 4 bacteria except staureus. It suggested that the colony diameters of penicillium chrysogenum and streptomyces jinyangensis (5406) increased significantly in $24 \mathrm{~h}$, suggesting the colonies grow continually. 


\section{3) The composite NF membranes surface crosslinked with different crosslinking agent showed different inhibition effects on the bacteria}

The composite NF membranes crosslinked with HDI showed better inhibition effects than those crosslinked by $\mathrm{GA}$ and $\mathrm{ECH}$. It might be related to the occurring positions of the crosslinking reactions. GA mainly reacts with the amine groups of SCS and NOCC, while HDI react with both amine and hydroxyl groups. The anti-bacterial abilities of chitosan and its derivatives are originated from the density of $-\mathrm{NH}_{3}{ }^{+}$ [23].

\section{CONCLUSIONS}

The anti-alga and anti-bacterial effects of SCS and NOCC composite NF membranes were investigated preliminarily. The adsorptions of freshwater alga on the composite NF membranes were less severe than those on the support membranes, PAN and PS UF membranes. It suggested that SCS and NOCC composite NF membranes have anti-alga and antifouling properties in certain degrees.

The anti-bacterial tests suggested that all the investigated composite NF membranes have some inhibition effects on the five kinds of bacteria. The anti-bacterial effects are related to the active layer material of the composite NF membrane and the cross-linking agent, which might be due to the occurring positions of the crosslinking reactions.

\section{REFERENCES}

[1] Y. Peng and Y. F. Li, "Combined effects of two kinds of essential oils on physical, mechanical and structural properties of chitosan films," Food Hydrocolloid, vol. 36, no. 1, pp. 287-293, May 2014.

[2] H. K. No, S. P. Meyers, W. Prinyawiwatkul, and Z. Xu, "Applications of chitosan for improvement of quality and shelf life of foods: A review," J. Food Sci., vol. 72, no. 5, pp. R87-R100, Jun.-Jul. 2007.

[3] Y. Zhong, X. Y. Song, and Y. F. Li, "Antimicrobial, physical and mechanical properties of kudzu starch-chitosan composite films as a function of acid solvent types," Carbohyd Polym, vol. 84, no. 1, pp. 335-342, Feb. 11, 2011.

[4] J. Rhoades and S. Roller, "Antimicrobial actions of degraded and native chitosan against spoilage organisms in laboratory media and foods," Applied and environmental microbiology, vol. 66, no. 1, pp. 80-86, Jan. 2000.

[5] Y. Uchida, M. Izume, and A. Ohtakara, Preparation of Chitosan Oligomers with Purified Chitosanase and Its Application, Chitin and Chitosan, New York Elsevier Applied Science, 1989.

[6] N. R. Sudarshan, D. G. Hoover, and D. Knorr, "Antibacterial Action of Chitosan," Food Biotechnol., vol. 6, no. 3, pp. 257-272, 1992.

[7] B. K. Choi, K. Y. Kim, Y. J. Yoo, S. J. Oh, J. H. Choi, and C. Y. Kim, "In vitro antimicrobial activity of a chitooligosaccharide mixture against Actinobacillus actinomycetemcomitans and Streptococcus mutans," Int. J. Antimicrob. Agents, vol. 18, no. 6, pp. 553-557, Dec. 2001.

[8] G. Ikinci, S. Senel, H. Akincibay, S. Kas, S. Ercis, C. G. Wilson, and A. A. Hincal, "Effect of chitosan on a periodontal pathogen Porphyromonas gingivalis," Int. J. Pharm., vol. 235, no. 1-2, pp. 121-127, Mar. 2002.

[9] S. Hirano and N. Nagao, "Effects of Chitosan, Pectic Acid, Lysozyme, and Chitinase on the growth of several Phytopathogens," Agr. Biol. Chem. Tokyo, vol. 53, no. 11, pp. 3065-3066, Nov. 1989.

[10] X. F. Liu, Y. L. Guan, D. Z. Yang, Z. Li, and K. D. Yao, "Antibacterial action of chitosan and carboxymethylated chitosan," J. Appl. Polym. Sci., vol. 79, no. 7, pp. 1324-1335, Feb. 2001.

[11] L. Chen, Y. Du, and Y. Liu, Structure-Antimicrobial Ability Relationship of Carboxymethyl Chitosan, vol. 46, no. 2, 2000.

[12] S. Maya, S. Indulekha, V. Sukhithasri, K. T. Smitha, S. V. Nair, R. Jayakumar, and R. Biswas, "Efficacy of tetracycline encapsulated O-carboxymethyl chitosan nanoparticles against intracellular infections of Staphylococcus aureus," International Journal of biological macromolecules, vol. 51, no. 4, pp. 392-399, Nov. 2012.
[13] N. A. Mohamed and M. M. Fahmy, "Synthesis and antimicrobial activity of some novel cross-linked chitosan hydrogels," Int. J. Mol. Sci., vol. 13, no. 9, pp. 11194-11209, Sep. 2012.

[14] J. W. Song, H. D. Ghim, J. H. Choi, S. W. Ko, and W. S. Lyoo, "Preparation of antimicrobial sodium alginate with chito-oligosaccharide side chains," J. Polym. Sci. Pol. Chem., vol. 39, no. 10, pp. 1810-1816, May 2001.

[15] Y. Song, E. E. Babiker, M. Usui, A. Saito, and A. Kato, "Emulsifying properties and bactericidal action of chitosan-lysozyme conjugates," Food Res. Int., vol. 35, no. 5, pp. 459-466, 2002.

[16] B. Li, C. L. Shan, Q. Zhou, Y. Fang, Y. L. Wang, F. Xu, L. R. Han, M Ibrahim, L. B. Guo, G. L. Xie, and G. C. Sun, "Synthesis, characterization, and antibacterial activity of cross-linked Chitosan-Glutaraldehyde," Marine Drugs, vol. 11, no. 5, pp 1534-1552, May 2013.

[17] S. Tripathi, G. K. Mehrotra, and P. K. Dutta, "Physicochemical and bioactivity of cross-linked chitosan-PVA film for food packaging applications," International Journal of Biological Macromolecules, vol. 45 , no. 4, pp. 372-376, Nov. 1, 2009.

[18] J. Miao, G. H. Chen, and C. J. Gao, "A novel kind of amphoteric composite nanofiltration membrane prepared from sulfated chitosan (SCS)," Desalination, vol. 181, no. 1-3, pp. 173-183, Sep. 5, 2005.

[19] J. Miao, L. C. Zhang, and H. C. Lin, "A novel kind of thin film composite nanofiltration membrane with sulfated chitosan as the active layer material," Chem. Eng. Sci., vol. 87, pp. 152-159, Jan. 14, 2013.

[20] J. Miao, H. C. Lin, W. M. Wang, and L. C. Zhang, "Amphoteric composite membranes for nanofiltration prepared from sulfated chitosan crosslinked with hexamethylene diisocyanate," Chem Eng $J$, vol. 234, pp. 132-139, Dec. 2013.

[21] J. Miao, G. H. Chen, C. J. Gao, C. G. Lin, D. Wang, and M. K. Sun, "Preparation and characterization of N,O-carboxymethyl chitosan (NOCC)/polysulfone (PS) composite nanofiltration membranes," $J$. Membrane Sci., vol. 280, no. 1-2, pp. 478-484, Sep. 1, 2006.

[22] J. Miao, G. H. Chen, C. J. Gao, and S. X. Dong, "Preparation and characterization of N,O-carboxymethyl chitosan/Polysulfone composite nanofiltration membrane crosslinked with epichlorohydrin," Desalination, vol. 233, no. 1-3, pp. 147-156, Dec. 15, 2008.

[23] H. Liu and Y. M. Du, "Antibacterial properties of chitosan and its derivatives and research progress in its application: anti-bacterial properties, influence factors, antibacterial mechanism," in Proc. the Fourth Chitin Technology and Applications Symposium, Beihai, China, 2004, pp. 62-66.

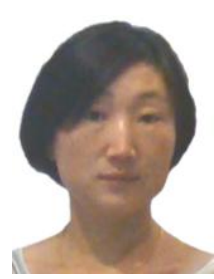

J. Miao was born in China. She is a research assistant at Edith Cowan University. She got the B. Sci. and M. Sci. degrees in applied chemistry and physical chemistry, respectively, from Shandong University, China. Her research interests are modeling and simulation with Finite Element method (FEM), functional polymers, membrane science and technology, photocatlysis, nanomaterials prepared through hydrothermal and mechanical methods, etc.

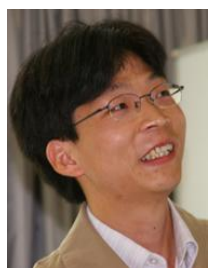

H. C. Lin was born in China. He received his $\mathrm{PhD}$ degree in organic chemistry from Lanzhou University and Shanghai Institute of Organic Chemistry, Chinese Academy of Sciences. He did post-doc research in Regensburg University and University of Saarland (Humboldt Fellowship). He then worked as a scientist researcher in Leibniz Institute of New Materials. From September in 2007, he joined in East China Normal University as an associated professor. His present research mainly focuses on the development of the advanced photopolymerizable materials, the synthesis of nanomaterials and conductive printing inks for the industrial cooperation projects.

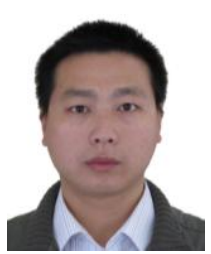

L. C. Zhang was born in 1977. He is an associate professor in the School of Engineering at Edith Cowan University. He received his $\mathrm{PhD}$ degree in materials science and engineering from the Institute of Metal Research, Chinese Academy of Sciences, Shenyang, China in 2005. Before he took the current position, he spent three years at The University of Western Australian, University of Wollongong, IFW Dresden, and Technische Universität Darmstadt. His research focuses on selective laser melting, lightweight alloys and composites, membrane, photocatalyst and biomedical implants and devices. 


\section{Environmental Quality Monitoring}


